\title{
Understanding Learning Experience and Knowledge Acquiring by Blind and Visually Impaired Students at the State Conservatory of Uzbekistan
}

\author{
Munavara Abdullaeva \\ The state conservatory of Uzbekistan \\ Shokhida Gafurova \\ The state conservatory of Uzbekistan, shahida@yandex.ru
}

\begin{abstract}
This paper provides insights into the challenges encountered by blind and visually impaired students in an inclusive setting at the State Conservatory of Uzbekistan. This study aimed at providing awareness about the visually disabled students' needs in the higher musical educational establishments. The paper explored whether the inclusive social environment at the State Conservatory of Uzbekistan has been suitable for visually impaired students and the implications and solutions required to improve learning environment. The education process should take into account the individual needs of visually disabled students to provide equal education. The paper proposes what needs to be done to create favorable learning conditions for blind students, like using suitable methods in the educational process, along with ensuring the availability of information resources and technologies. New teaching methods, as well as approaches adapted to the individual needs of visually impaired students, will create optimal conditions for learning, which, in turn, will contribute to better socialization of blind students. The paper explicitly focuses on how blind and visually impaired students have been taught the English language at the State Conservatory of Uzbekistan. The article examines the techniques the teachers utilize to teach visually impaired students in an inclusive environment. The study has found that most learners with visual impairments performed no worse than their sighted fellow students in academic performance.
\end{abstract}

Keywords: blind and visually impaired students, socialization, perception, imagination, memory, creative thinking, motivation, inclusive education, listening

Follow this and additional works at: doi.org/10.52847/EAMSJ

\section{Recommended Citation}

Abdullaeva, Munavara and Gafurova, Shokhida (2021) "Understanding Learning Experience and Knowledge Acquiring by Blind and Visually Impaired Students at the State Conservatory of Uzbekistan," Eurasian music science journal: 2021 : No. 1 , Article 1.

Available at: https://eamsj.uz/index.php/eamsjournal/article/view/51

DOI: https://doi.org/10.52847/EAMSJ/vol_2021_issue_1/51

This Article is brought to you for free and open access. It has been accepted for inclusion in Eurasian music science journal (www.eamsj.uz). All copyrights to articles (preprint, postprint and version of record) belong to their authors and do not pass to anyone. PDF versions of scholarly articles are in open access under the Attribution Non-Commercial No Derivatives CC BY-NC-ND licence. 
Introduction. Teaching the blind and visually impaired students have been an overly profound issue in contemporary society, even more during the pandemic. The need to provide equal rights to the people with disabilities to enjoy all the benefits of society, especially in gaining access to higher education has been mentioned in the United Nations Convention on the Rights of Persons with Disabilities (CRPD). It states, "State parties shall ensure that persons with disabilities are able to access general tertiary education, vocational training, adult education, and lifelong learning without discrimination and on an equal basis with others" [1]. Starting from the 2018-2019 academic year, the admission quota to universities for people with disabilities raised to $2 \%$ of the total number of applicants, by the decree of the President of Uzbekistan dated December 1, 2017, "On measures to radically improve the system of state support for persons with disabilities" [2]. Measures envisaged granting preferential rights when entering universities for people with disabilities. The government introduced the two percent quota for people with disabilities to overcome inequality and ensure access to higher education in a highly competitive environment among all applicants. The quota for people with disabilities has been a point of entry towards making higher education accessible to this category of persons [3] to enhance social integration. Therefore, it turns out to be beneficial not only to the blind students but to all other students. In recent years, the Higher Educational systems in Uzbekistan has been struggling to become disability-inclusive to meet international obligations and global frameworks. Uzbekistan follows the Sustainable Development Goals (SDGs), planning to build a better world for people by 2030 . The 'SDG 4' aims to ensure inclusive and equitable quality education and promote lifelong learning opportunities for all [4].

It is widely known, that blind students in educational institutions experience numerous challenges due to their visual impairments, which adversely affect their academic performance. The state policy of Uzbekistan aimed at increasing access to education for everyone, including people with disabilities. It 
is considered that after completing training at a higher educational institution, a blind person would become a competitive and a full-fledged person. However, "attending a higher educational institution and obtaining a degree can be an overall overwhelming challenge for students with visual disabilities, lead to certain autonomies of a person, and reach a certain quality of life" [5 p. 24]. The visually impaired students are a mixed group with various difficulties that require sufficient consideration to achieve good academic performance when they are placed in regular inclusive institutions. "The barriers to inclusive education are well-understood now and include inadequacies in policy and legal support, resources and facilities, specialized staff, teacher training, pedagogical techniques, flexible curricula, supportive leadership, and cultural attitudes" [6 p. 2].

Mastering foreign languages enables people with vision problems to express themselves and increase their social life, thus contributing to the socialization of blind people. Accordingly, new perspectives open up for people with knowledge of a foreign language, including expanding the opportunity to get a job, despite the physical disability in the form of a lack of vision. When receiving music education, learning a foreign language is extremely important for people with disabilities with partial or complete blindness. Knowledge of foreign languages for such people will increase their chances to obtain better job opportunities and enhance their ability to adapt to social life [7, 8]. Whatever their future profession, knowledge of a foreign language expands the educational capabilities of blind people, allowing them to be introduced to the global environment and feel socially adopted. With the correct development of new approaches to the training system, including the appropriate construction of the educational process in higher educational institutions, students with disabilities could join the learning process and apply their knowledge in future professional activities. The inclusion of blind students in a full-fledged education can significantly increase the level of cognitive development of the visually impaired 
students. It can enhance perception, imagination, memory, and even abstract thinking. English can help integrate the blind and visually impaired in the information space. For example, on the Internet, English is one of the main ways of communication. With the help of audio programs in a foreign language, a blind person may receive much more information he needs in his major. Scientific and technological progress with the help of special programs and devices provides people with limited vision more and more opportunities to assimilate educational material. Modern computer technologies bring forth valuable assistance, such as online testing, the use of specially programmed sites, internet simulators, among others. For visually impaired students listening is one of the best ways to get the information they need to master what they get during learning. Learning English by ear is a difficult task, but in the absence of sight, the most effective sensory organ with which a blind person can identify an object at a distance is hearing. The studies note that in most cases, blindness stimulates the development of hearing [9].

The literature review has revealed that the brain of a visually impaired person and a sighted one has no functional differences and their mental capacities are in many ways equal [9]. Nevertheless, the development of the blind and visually impaired person is to a certain extent different from the development of people with normal vision $[7,9]$ It is argued, that the periods of memorizing the material for the visually impaired students could be longer in time compared with the sighted students [10]. Consequently, in order for these students to adapt easier to the educational process, it is necessary to create favorable conditions for their development.

The in-depth review of the literature undertaken by Ediyanto et.al. revealed that visually impaired students, despite the enormous challenge, could grasp concepts about science because visually impaired students have the same range of cognitive abilities as the other students. However, "they learn with orientation, tactile and kinesthetic learning, auditory learning and accommodations, and 
assistive technology" [11 p. 7]. Süleyman Başaran, in turn, argues that those students who were blind early in life could not develop a concept of perspective. However, not being able to develop concepts does not mean that the blind and the visually impaired individuals cannot be good language learners [12].

Many studies have discussed and identified the difficulties faced by visually handicapped students in higher educational institutions [13, 14, 15, 16]. The authors indicated such problems as few Braille printed books, lack of visual readers, the difficulty of adjustment with university life, neglect of visually impaired special needs, and the problem of taking exams as well as transportation. Among other obstacles were the fast rate of the teachers' speech during the lectures, difficulty in participating in the discussion and answering the questions, hard access to the educational centers with a lack of suitable computer programs [17]. The study undertaken by Otyola W. et. al. revealed that during the teaching process, the visually impaired students have been slow while writing and taking notes while their Braille machines also made a lot of noise for both the students and interrupted with the lecturers' dictations [18]. Sahin argued that blind and visually impaired students might have required print materials in alternative formats such as materials converted to audiotapes, scanned onto disks, enlarged or imaged enhanced, and Braille [19 p. 25]. According to Habulezi et.al., most teachers had not enough training in the teaching and learning methods for students with special educational needs.

"...the majority of the teachers lack adequate preparation for their lessons in that they may prepare for the mainstream students but forget that there are students who are blind who may need to be brailled, enlarged, embossed, or recorded teaching and learning materials" [20 p. 39].

Among other challenges identified in the study undertaken by Dr. Radhika Kapur, were the students' evaluation process. It was based not on their capability and specific educational needs, but their performance, in-class tests and assignments. He argued that in inclusive teaching, a normative kind of assessment 
dominated since teachers were "not educated enough in sign language, use of Braille materials, preparation of hearing aids, tactile diagrams and maps and so forth" [21 p. 8]. Dr. Saranjit Kaur described the problems faced by visually impaired students, which impacted their performance. The author argued that to improve the situation the university should have taken efforts to provide laptops, scanners, and software for disabled and audiovisual rooms and other digital facilities. Among other challenges identified in the study undertaken by Dr. Radhika Kapur, were the students' evaluation process. It was based not on their capability and specific educational needs, but their Additionally, disabled students should be given the facility to get the required books scanned or get audio prepared, as well as staff, should be available for that [21 p. 59]. The literature review indicates that despite the obstacles and hurdles, visually impaired students can study well if there are appropriate supporting tools for them to learn and that when "the special and unique needs of visually impaired students met, they can learn any foreign language like their sighted counterparts" [23. p. 101]. It was believed that the way the blind students and visually impaired perceive the classroom activities quite differently from those without any impairment [24]. Therefore, techniques that are used to educate the visually impaired in general, teaching them English in particular, and theoretical assumptions underlying such teaching or instruction are supposed to be different. That consumption was based on the earlier beliefs that the blind person could not develop particular concepts since their understanding was limited by the diminished visual abilities. However, Süleyman Başaran argues that visually impaired students "tend to use words whose concrete referent is unknown to them, which is called verbalism" [12. p. 218]. That means that students could easily talk about the things they had never seen. Ediyanto et.al argued that students with visual impairment apparently have the same cognitive abilities range and can master higher-order science concepts as well [11 p. 1]. 
Methodology. The blind and visually impaired students represent a small portion of the State Conservatory of Uzbekistan and the system has built inclusive settings with both visually impaired and sighted. The study hypothesized that the students with visual disabilities, being together with students with normal vision in the foreign language classes, could be more beneficial than studying in a specially structured environment.

The sample in this study consisted of students with visual disabilities and three English teachers. The second-year male and female students from the pop singing department, one male student third-year from the sound engineering department, and two male graduate students from the traditional performance department, all visually impaired, were interviewed and observed during the English classes. The study was carried out with participants in two settings, namely in the classroom for observation and outside the classroom for interviews. The in-depth interviews were conducted with the visually impaired students and their teachers.

The study aimed at collecting data about teaching the English language to blind and visually impaired students in the inclusive class. It followed the obstacles the blind and visually impaired students faced during the learning process and learning needs.

It is believed, that blind students find it rather difficult to keep up with the process and catch what is happening on a par with sighted students $[4,11,12]$. Moreover, students who are blind may also be uncomfortable, have low selfesteem, and lack motivation [4, 7]. Our study has explicitly focused on how blind and visually impaired students have been taught the English language at the State Conservatory of Uzbekistan. Educational settings in the Uzbekistan State Conservatory have been created in such a way that it is inclusive of both visually impaired and sighted students in all classes, be it a major or minor subject.

The study analyzes the techniques and materials that teachers utilize to teach the visually impaired in an inclusive environment while teaching English 
as a foreign language and the challenges they both have been facing during the education process. Data was generated through interviews and observation. Observations were made during the learning process.

During the qualitative research, three English teachers of the "Uzbek and foreign languages" department of the State Conservatory of Uzbekistan were interviewed, along with five visually impaired students. Observation notes were utilized to evaluate interview data and to draw conclusions. The first interview and observation were conducted with five blind students of "pop singing", "sound engineering", and "traditional performance" departments. Further interviews were carried out with the three teachers of the "Uzbek and foreign languages" department. Semi-structured interview questions were prepared and discussed with the teachers to avoid misconceptions. The teaching process was also observed to get an insight into teaching methods, views, and conceptions of the challenges and practices.

The respondents, both the students and the teaching staff, were eager to participate in the process. The student respondents were rather talkative and openly talked about all issues. The visually impaired students were asked about academic as well as social challenges they encountered.

The observation focused on the problems that the teachers encountered while teaching, the strategies they used to overcome difficulties, as well as their teaching techniques and materials used.

Observation also provided insight into the students' performance of tasks. The three lessons observed were different in teaching methods, but almost identical in terms of the materials used except for the specific grammar topics that the teachers taught. Two blind students, a female (19 years old) and a male (23 years), were present in the first class, one partially visually impaired student (25 years old) in the second class, and two male students (18 and 25 years old) in the third class. The three lessons were conducted at a different time as the blind students pursued various specialties. 
In the first lesson observation, the teacher required the students to read the text from the coursebook one by one. Students read a sentence in the textbook and orally translated it into Uzbek. Speaking loudly, the teacher corrected the pronunciation of incorrectly pronounced words. The second class started with the pre-reading section, the teacher asked several questions while listening to the answers corrected mistakes and pronunciation. In the third class, the teacher also started the lesson by reading the text. At each lesson, the teachers introduced grammar after reading and explained grammar structures orally in Uzbek. When the teachers asked to write the sample sentences in the English language, the blind and visually impaired students were writing down in Braille. However, neither of the teachers could check whether they were writing the correct words since they did not know Braille. Further, the teachers asked the students to make sample sentences. When the blind students were in doubt about what the teacher was dictating, the latter spelled it to help them write it correctly. The students actively participated in the lessons. However, they did not read the texts provided but translated what other students were reading from the textbooks since the textbooks used in the classwork were ordinary, not the Braille ones.

Sometimes it was necessary to read aloud several times in a row for the blind to grasp the meaning. The main objective was to keep all students in the class as engaged as possible at all times. During the interviews, the teachers reported that they did not have many difficulties involving the blind students in the class activities. Although it was challenging for them to teach blind students since neither had formal training about teaching English to students with visual impairments. They stressed that the blind students were eager to talk and actively participated during lessons. The blind was mainly engaged in translating what other students read. They answered the questions because they were not able to read from the course books. The teachers conveyed that they tried to make their lessons more communicative through the questions and answer techniques. The 
teachers utilized the same teaching techniques and materials commonly used in the State Conservatory of Uzbekistan to teach sighted students.

The teachers argued that the most important thing for them was to reach out to all students with varying needs and to ensure the highest degree of probability that their students learn English.

Analysis of the interviews clearly showed that visually impaired students were not different from the sighted students, in terms of participation in classroom activities, and the classroom observations verified that. They did not doubt that they were not somehow different from other students. The blind students tended to interact more with their sighted peers. It was observed that blind and visually impaired students participated in interaction on a par with sighted students and sometimes they appeared to be more active during and after the lessons. The visually impaired students-initiated interactions at a higher rate than did the students without visual impairments.

During the interviews with the blind students, the question was posed on whether small homogenous groups should be formed to assign students with similar characteristics to the same class. All the respondents consistently answered that they had no problems studying with other sighted students. Moreover, they stressed that they are eager to communicate and felt connected to the outer world much more than when they studied in specialized schools.

There is no special curriculum designed for visually impaired students. The observation and interviews suggested that the adaptation potential of blind students goes faster in the team, allows them to feel more confident with their peers, and helps them to look into the future with the hope that they would be able to build their careers more successfully. On the other hand, in joint group classes, there is a possibility that by paying attention to blind students, the teachers have to adjust the educational process to the detriment of other students. Therefore, in groups where blind students are educated, the educational process should be built more explicitly. The teachers need to get more training on how 
to organize inclusive classes. Inclusive classes are essential because it promotes healthy competition amongst students who are blind and motivation for the sighted students. The inclusion of blind students in the education process enhances the social integration of visually impaired students and allows them to prepare them for their future roles in society $[4,6,12,14,27]$.

During the interviews, it was identified that the visually impaired students relied much on fellow students and assistance from the teachers' side to succeed academically. In all learning situations, such as accessing internet resources, reading modules, and completing assignments, the other conservatory students eagerly assisted. Their classmates were keen to help them find themselves in the conservatory building, taking them to the cafeteria, library, or other places. Only a female blind student was accompanied by her mother, sometimes her brother.

During class teaching, the teachers kept visually impaired students' insight in order to provide them with the necessary help and support in time. Students reported that they would not like to have a special attitude towards them; everyone reported that they often feel uncomfortable during the lesson due to the fact that they drew too much attention to themselves. The study suggested that unrelated sounds should be minimized in the classroom, while the teacher pronounces the names of the students so that it was clear to whom the teacher referred and whose turn it was to answer. The blind students said that they cannot but help but hear all the sounds around, so they have to strain to distinguish the right sounds from the background sounds. By making it clear to the blind student when it was his turn to answer, the teacher encourages the blind student to keep up and actively participate in the learning process. Thus, the teachers should be precise about the correct words and phrases when they give an assignment to students, as well as when using the board. It would also be advisable that the teacher help in mastering the correct pronunciation and articulation of speech sounds since a blind student is deprived of the opportunity to observe the lip movement of a speaking adult. In our study, none of the blind students had trouble 
with the pronunciation of English words. Most likely because they all have nearly perfect pitch due to the specifics of their musical education.

Among the issues encountered by the visually impaired students were the inadequate supply of writing and reading equipment such as Braille machines, laptops, and computers. Visually impaired students named the lack of Braille textbooks and paper as the main challenge. They said that both were very expensive. The respondents also mentioned that the Braille alphabet in Russian has been much more adaptable than Uzbek. However, the students didn't complain about mobility problems, negative attitudes, no competition with other students, or deprived attention in the class due to noise. None of the interviewed students complained about not being assessed well or appropriately. These answers do not correspond with the findings from some researches that studied challenges faced by disabled students in universities $[12,18]$.

The observations suggested that the teachers, although being aware that it was undesirable to ask students to look at the blackboard while explaining the material, they nevertheless applied such methods. They should rather speak aloud about what is written on the board since blind students perceive everything by ear. The teachers should always keep in mind that so far, listening is the main manageable way of teaching visually impaired students.

The learning and teaching process in the State Conservatory of Uzbekistan has been reorganized after the introduction of distance education in April 2020 due to the coronavirus pandemic. Classes continued through the MOODLE learning platform and Zoom cloud-based video conferencing service. Although the ultimate goal of distance learning is to make education available to anyone, it cannot produce the best results unless courses are designed to be accessible to all potential students, including those with disabilities. No one denies the fact that digital technologies are of foremost importance in developing language skills. With the help of the internet, blind students may have access to the same means of information as sighted people and on the same terms. The policy towards 
digitalization in Uzbekistan has now been confirmed a priority, therefore digitalization services at the conservatory have been fully accessible. All blind and visually impaired students admitted that they could independently use computer technology. However, blind students have to purchase adaptive technology to make the computer corresponds to their needs. Consequently, the resulting information gap may create a "digital divide" between those who can benefit from opportunities provided by information technologies and those who cannot [25 p. 2].

As Burgstahler et al., argues:

“...individuals who are blind often use text-to-speech systems that read what appears on the computer screen with a synthesized voice. These systems only provide access to the text content of Web pages, software, and other electronic resources. Text-based course tools such as electronic mail do not present accessibility challenges to people who are blind, but content embedded in graphic images is inaccessible unless text descriptions are provided" [26 p. 235].

Moreover, the teaching staff lacks substantial experience in offering Internet-based lessons adapted both for the blind and sighted students. Teaching foreign languages to blind students requires a special system of measures and specific didactic materials. This set of measures implies the technical equipment of educational institutions and the development of special training courses for teachers and other students on interaction with blind students. Besides, special programs are needed to adapt them in the educational institution with inclusive teaching.

Teachers need to start developing their methods of working with such students, built solely on the provision of material by ear. The teacher being aware of the presence of students with disabilities in the group should not put the same requirements for the blind as for sighted students, although they are examined on the same subject content with their peers. The designed programs for many 
courses, including English courses, were not fully accessible to potential students with disabilities because of the inaccessible design and communication methods. One of the students argued:

"For me, the biggest problem is that I cannot read information or do any assignments on the MOODLE platform. You have to download information from the platform and ask someone to read it. I want to study on my own, but no speech synthesizer can read scientific literature in Uzbek."

At such a time, a student with disabilities may be left alone, but the teachers should not let them move away from the outside world. One respondent said that during the pandemic, he became separated from society, while the online education environment has required much effort to be put into it.

Another issue is that during knowledge testing and exams, the teacher must modify the tests to suit the needs of the blind students. Although these students didn't complain about attending mainstream lectures and being examined on the same subject content with their classmates, they need some adjustments and should be provided with more time to do the tests.

Another challenge is that there are not enough textbooks for teaching visually impaired students yet. Thus, to provide the blind students with the education that meets modern requirements, it is, necessary to increase the methodological developments, as well as a highlight in the scientific literature the successes and errors of the experience of working with blind students. Notably, the teacher should try to understand the visual capabilities of the student and the degree of his/her blindness, to be able to provide better teaching service to the latter.

Some students have lost their sight in their early years, while some have congenital vision problems. It is essential to find out when the student has lost sight, as if it is not a congenital abnormality, the student may retain visual memories. The approach to such students should be different. It is worth mentioning that all the blind respondents were very active during the interviews 
and happily answered questions, seemed satisfied with life, never complaining about the circumstances. They said they were happy to return to the traditional education process. The respondents did not complain about the educational process or inappropriate attitude from their classmates or teachers. They all looked happy and satisfied.

Conclusion. The findings of the study indicate several implications. Such as the need for:

i) inclusion of visual impairment issues into informal training of EFL teachers;

ii) development of special EFL teaching techniques and materials for the visually impaired students;

iii) creation of inclusive settings and favorable conditions to satisfy the needs of both visually impaired students and sighted students.

Teaching English language to people with disabilities requires qualified personnel. There are no fully integrated techniques yet, that are fully refined and ready to be used by the blind [27] In the context of giving students more autonomy, adopting a more student-centered approach and adherence to the principles of learner independence, it must be borne in mind that the needs of blind, and sighted students may differ. In this case, the teachers' special training is required. The study showed that the teachers had not any special training in teaching blind students. To enhance learning productivity the teachers should be provided with adequate training to satisfy the educational development of persons with disabilities since trained teachers could be more fruitful in the achievement of quality and relevant education. The most important implication for Uzbekistan national education policy has been to introduce the retraining vocational programs for English language courses about teaching students with special needs. If the teachers and those who are responsible for ensuring a well-organized learning process could be able to approach the problem to overcome the negative 
aspects of vision loss, the blind students could reach similar levels of achievement in foreign language education like sighted people.

In a rapidly changing world, new technologies are gaining more and more place in the educational process. All five students answered that they use the latest technology resources, are well versed in the latest different mobile applications, video-streaming programs as well as sites. They also use learning systems and many other capacities of modern technologies. That gives them a unique opportunity to study with the help of these devices. The two of the students reported using a variety of resources with the screen reader technology such as Non-Visual Desktop Access (NVDA) and Job Access with Speech (JAWS). These findings suggest that visually impaired students have unique opportunities and ways of learning foreign languages supported by assistive technology.

These abilities should be acknowledged to obtain the perspectives of students who receive disability-specific education. It is necessary to develop a website for the visually impaired to communicate with each other so that through webinars the blind from different areas could get access to virtual lessons, where tested lessons were downloaded with the ability to reach out to the teacher at the appropriate time. All materials can be used as training simulators.

During the lesson observations, the teachers did not use the video materials [28] However, the presence of blind students in the classroom should not stop the usage of video materials and other demonstrative means. When using the video material, the teachers should discuss in advance what scenes to be shown [29] It is necessary to comment on what is happening on the screen during the demonstration. The students will not feel dropped out of the lesson. During the interviews, the blind students did not reveal discontent with the demonstration of video during lessons. However, a personal discussion with blind students about the problems they were worried about and the best way to work out those problems might help students be better involved in the educational process. 
The blind students should also be given plenty of time so that they manage to write down and assimilate the material. The tests and exams must be administered orally to visually impaired students (which is usually taking place). Testing students' knowledge is part of the learning process and is also necessary for blind students to track their progress and get feedback on their work. The usual examination format should be adapted to suit the needs of students who are blind. The teachers should clearly explain the examination requirements well in advance and provide extra time to the students. For all these reasons, it is necessary to accentuate the issues of visually impaired students. The educational settings should be adapted considering the special needs of blind and visually impaired students.

The distance learning courses should be designed in such a way that the blind students may have access to the same means of information as sighted people and on the condition of equality [30].

Thus, with due diligence and assistance, we can achieve impressive results in helping blind students learn a foreign language. It is also essential to arrange an appropriate environment in the educational institution. Visually impaired people have all the necessary inclinations for successful learning and prosperous life. With proper socialization, they can turn out to be no less useful for society, as healthy people. If the visually impaired and blind students are given this opportunity, they can learn anything and achieve the same success as their sighted peers.

\section{References:}

[1] Convention on the Rights of Persons with Disabilities (CRPD). United Nations Enable.

[2] http://lex.uz/docs/3436196. 
[3] Yusupov, D. (2019). Uzbekistan: Kak obespechit dostupnost vysshego obrazovaniya dlya lyudey $\mathrm{s}$ invalidnostyu? [Uzbekistan: how to ensure accessibility of higher education for people with disabilities?] Analitika. Retrieved from https://cabar.asia/ru/uzbekistan-kak-obespechit-dostupnostvysshego-obrazovaniya-dlya-lyudej-s-invalidnostyu.

[4] Thompson, S. (2020). Developing disability-inclusive higher education systems. International Higher Education, №100. Retrieved from https://www.universityworldnews.com/post.php?story=20200122104602834.

[5] Bilgeri, M. (2017). Education for children with disabilities in Addis Ababa, Ethiopia. Inclusive Learning and Educational Equity, Vol. 4, pp. 4213.

[6] Schuelka, M. (2018) Implementing inclusive education. Retrieved from https://assets.publishing.service.gov.uk/media/5c6eb77340f0b647b214c599/374 _Implementing_Inclusive_Education.pdf.

[7] Gritsishina, N., Gureva, L. (2011). Sposoby obucheniya slepyh i slabovidyashih inostrannomu yazyku $\mathrm{s}$ primeneniem igrovyh texnologiy [Methods of teaching the blind and visually impaired a foreign language using gaming technologies]. Syktyvkarskiy Gosudarstvennyi Universitet Almanax Sovremennoy Nauki i Obrazovaniya [Syktyvkar State University Almanac of Contemporary Science and Education]. № 4, (47).

[8] Minina, O., Rocheva, N., Konevskaya Y. (2011). Metodika individualnogo obucheniya slabovidyashix studentov angliyskomu yazyku. Inklyuzivnoe obrazovanie: metodologiya, praktika, texnologii [Methodology of individual teaching English to visually impaired students. Inclusive education: methodology, practice, technology]. Retrieved from https://psyjournals.ru/inclusive_edu/issue/44237.shtml. 
[9] Alekseeva, N., Fisunov, P. (2017). Analiz sovremennogo sostoyaniya pedagogicheskix issledovaniy $\mathrm{v}$ oblasti obucheniya slepyx i slabovidyashix inostrannomu yazyku [Analysis of the current state of pedagogical research in the field of teaching foreign languages to the blind and visually impaired]. Voprosy Lingvodidaktiki i Perevodovedeniya: Sbornik Nauchnih Statey [Questions of Linguodidactics and Translation Studies: Collection of Scientific Articles]. Cheboksary. pp. 3-6.

[10] Mezenseva, N., Oleynikova, S., (2014). Osobennosti obucheniya angliyskomu yazyku lyudey s otkloneniyami zreniya [Features of teaching English to people with visual disabilities]. XVIII Studencheskaya mejdunarodnaya nauchno-prakticheskaya konferensiya "Nauchnoe soobshestvo studentov XXI stoletiya” [XVIII Student International Scientific and Practical Conference "XXI century Students Scientific community”]. Novosibirsk, 6 March. pp. 72-78 3. Retrieved from https://sibac.info/studconf/hum/xviii/37178.

[11] Ediyanto and N Kawai (2019). Science learning for students with visually impaired: a literature review J. Phys. Conf. Ser. 1227 012035. Retrieved from https://www.researchgate.net/publication/333874064_Science_Learning_for_St udents_with_Visually_Impaired_A_Literature_Review.

[12] Basharan, S. (2012). Teaching English to visually impaired students in Turkey: A case study. Social and Educational Studies. Energy Education Science and Technology Part B: Social and Educational Studies. Special Issue 2, pp. 217226.

Retrieved from https://www.researchgate.net/publication/281780906_Teaching_English_to_vis ually_impaired_students_in_Turkey_A_case_study.

[13] Manar, M., Rochyadi, E., Sunardi, M. (2018). A case study of students with visual disabilities in inclusive higher education. Advances in Social Science, Education and Humanities Research, Vol. 272. 2nd International Conference on 
Indonesian Education for All (IC-INDOEDUC4ALL). Retrieved from https://www.atlantis-press.com/proceedings/indoeduc-18/25906693.

[14] Kocyigita, N., Artar, P. (2015). A challenge: Teaching English to visuallyimpaired learners. Procedia - Social and Behavioral Sciences, №199 pp. 689 694. Retrieved from https://cyberleninka.org/article/n/1237387.

[15] Noor, A., Mujani W. (2016). Issues and challenges of education for disabilities (blind) in muslim community in malaysia by using braille. International conference on education, e-learning and management technology (EEMT). Retrieved from https://doi.org/10.2991/iceemt-16.2016.124.

[16] Majoni, C., Mashatise J. (2017). Challenges faced by students with blindness studying through open and distance learning. European Journal of Research in Social Sciences, Vol. 5 No. 2.

[17] Fuller, M., Healy, A., Bradley, \& Hall, Y. (2004). Barriers to learning, a systematic Study of the experience of disabled students in one university. Studies in Higher Education, 29 (3), pp. 303-318.

[18] Otyola, W., Kibanja, G., Mugagga, A. (2017). Challenges faced by visually impaired students at makerere and kyambogo universities. Makerere Journal of Higher Education, ISSN: 1816-6822; 9 (1) 75 - 86 DOI: http://dx.doi.org/10.4314/majohe.v9i1.

[19] Sahin, M. (2009). Teaching science to visually impaired students: a smallscale qualitative study. Vol. 6, No.4 (Serial No.53) Retrieved from ttps://www.researchgate.net/publication/234621446_Teaching_Science_to_Visu ally_Impaired.

[20] Habulezi, J., Molao, O., Mphuting, S., Kebotlositswe, K. (2016). Inclusive education and challenges of providing classroom support to students with blindness in a general education classroom at a school in Botswana. International 
Journal of Learning, Teaching and Educational Research, Vol. 15, No. 1, pp. 3041.

[21] Kapur, R. (2018). Challenges experienced by visually impaired students in education. Retrieved from https://www.researchgate.net/publication/323833804. [22] Kaur, S. (2018). Challenges in teaching and learning for visually impaired. International Journal of Engineering Science Invention (IJESI), Vol. 7, Issue 6, Ver, II. pp. 57-59.

[23] Arslantash, T. (2017). Foreign language education of visually impaired individuals: a review of pervasive studies. Ihead, e-ISSN 2528-9632, 2(2), pp. 95-104.

[24] Churton, M. (2002). The utilization of distance learning and technology for teaching children with disabilities. In JL. Paul (Ed.), Rethinking Professional issues in special education. Westport: Greenwood Publishing Group, Incorporated, USA, pp. 251-266.

[25] Arrigo, M. (2005). E-Learning Accessibility for blind students. Recent Research Developments in Learning Technologies. Retrieved from https://www.researchgate.net/publication/228613727_Elearning_accessibility_for_blind_students.

[26] Burgstahler, S., Corrigan, B., MacCarter, J. (2004). Making distance learning courses accessible to students and instructors with disabilities: A case study. The Internet and Higher Education, Vol. 7, Issue 3, 3rd Quarter 2004, pp. 233-246. https://doi.org/10.1016/j.iheduc.2004.06.004.

[27] Asanbaev, A., Kutebaev, T., Axmetova, G. (2015). Obuchenie angliyskomu yaziku lyudey s ogranichennimi vozmojnostyami posredstvom kompyuternoinnovatsionnyh texnologiy i elektronnyh uchebnikov $\mathrm{v}$ selyah integratsii $\mathrm{v}$ mirovoe prostranstvo [Teaching English to people with disabilities through 
computer-innovative technologies and electronic textbooks in order to integrate into the global space]. Mejdunarodny Jurnal Prikladnyh $i$ Fundamentalnyh Issledovaniy [International Journal of Applied Basic Research], № 6-2., pp. 327329. Retrieved from https://applied-research.ru/ru/article/view?id=6899.

[28] Ganikhanova, Sh. (2020). Film music of Uzbekistan in the context of the problem of the synthesis of arts. Eurasian music science journal, No. 2, Article 12. Retrieved from https:/uzjournals.edu.uz/ea_music/vol2020/iss2/12.

[29] Ganikhanova, Sh. (2019). The formation of multiplication in Uzbekistan (in the Problem of the Interaction of audio and video series). Eurasian Music Science Journal, No. 1, Article 2. Retrieved from https://uzjournals.edu.uz/ea_music/vol2020/iss2/12.

[30] Abdullaeva, M., Gafurova, Sh. (2020). Challenges, experience and efficiency of distance education system introduced in Uzbekistan's State Conservatory during pandemic. Eurasian Music Science Journal, No. 2, Article 8. Retrieved from https://uzjournals.edu.uz/ea_music/vol2020/iss2/8. 